\title{
Can scenario-planning support community-based natural resource management? Experiences from three countries in Latin America
}

\author{
$\underline{\text { Kerry A. Wavlen }}^{1}, \underline{\text { Julia Martin-Ortega }}^{1,2}, \underline{\text { Kirsty L. Blackstock }}^{1}, \underline{\text { Iain Brown }}^{3}, \underline{\text { Bryan E. Avendaño Uribe }}^{4}$, $\underline{\text { Saúl Basurto Hernández }}^{5}$ \\ ${ }^{5,6}$, María Belén Bertoni ${ }^{7}$, M. Lujan Bustos ${ }^{8,9}$, Alejandra Xóchitl Cruz Bayer ${ }^{5}$, Roberto Ivan Escalante Semerena ${ }^{5}$, Maria Adelaida \\ Farah Quijano $^{10}$, Federico Ferrelli $^{11,12}{ }^{\text {, Guillermo Luis Fidalgo }}{ }^{13}$, Israel Hernández López ${ }^{14}$, María Andrea Huamantinco Cisneros ${ }^{8}$, \\ $\underline{\text { Silvia London }}^{15,16}$, Diana L. Maya Vélez ${ }^{17}$, Natalia Ocampo-Díaz ${ }^{17}$, Cesar E. Ortiz-Guerrero ${ }^{17}$, Juan Carlos Pascale ${ }^{9}$, Gerardo M. E. \\ ${\underline{\text { Perillo }^{18,19}}}^{\text {M. Cintia Piccolo }}{ }^{8,9}, \underline{\text { Lina N. Pinzón Martínez }}{ }^{17}, \underline{\text { Mara L. Rojas }}^{15,16}$, Facundo Scordo $^{8,20}$, Valeria Vitale $^{13,15}$ and Mariana $^{17}$ \\ I. Zilio $^{21,22}$
}

\begin{abstract}
Community-based natural resource management (CBNRM) is a concept critical to managing social-ecological systems but whose implementation needs strengthening. Scenario planning is one approach that may offer benefits relevant to CBNRM but whose potential is not yet well understood. Therefore, we designed, trialed, and evaluated a scenario-planning method intended to support CBNRM in three cases, located in Colombia, Mexico, and Argentina. Implementing scenario planning was judged as worthwhile in all three cases, although aspects of it were challenging to facilitate. The benefits generated were relevant to strengthening CBNRM: encouraging the participation of local people and using their knowledge, enhanced consideration of and adaptation to future change, and supporting the development of systems thinking. Tracing exactly when and how these benefits arose was challenging, but two elements of the method seemed particularly useful. First, using a systematic approach to discuss how drivers of change may affect local social-ecological systems helped to foster systems thinking and identify connections between issues. Second, explicitly focusing on how to use and respond to scenarios helped identify specific practical activities, or "response options," that would support CBNRM despite the pressures of future change. Discussions about response options also highlighted the need for support by other actors, e.g., policy groups: this raised the question of when and how other actors and other sources of knowledge should be involved in scenario planning, so as to encourage their buy-in to actions identified by the process. We suggest that other CBNRM initiatives may benefit from adapting and applying scenario planning. However, these initiatives should be carefully monitored because further research is required to understand how and when scenario-planning methods may produce benefits, as well as their strengths and weaknesses versus other methods.
\end{abstract}

Key Words: Argentina; climate change; Colombia; community-based conservation; futures thinking; Mexico; participation; scenario methods; wicked problems

\section{INTRODUCTION}

Community-based natural resource management (CBNRM) is a hugely influential concept in natural resource management and conservation (Western et al. 1994). It is premised on the idea that people should be involved and empowered in the management of the social-ecological systems of which they are a part. When they are, this is thought to result in the most equitable and sustainable outcomes. However, experiences have not always matched expectations of CBNRM. A large body of literature has identified common problems with the conceptualization and implementation of CBNRM (e.g., Dressler et al. 2010, Shackleton et al. 2010). Many projects have relied on an oversimplified understanding of their context, in particular the influences on, and motivations of, local actors (Saunders 2014). Related to this, the design and implementation of projects is often static and inflexible, unable to take change into account (Armitage 2005). As a result, some projects have not fully involved or empowered all community members (Méndez-López et al. 2014), some have struggled to achieve their aims because of external pressures (e.g., Scholte 2003), and others have caused negative social and/or ecological impacts because of unintended side effects (e.g., Haller et al. 2008). CBNRM, therefore, needs strengthening; not doing so jeopardizes both ecosystems and the well-being of those people whose lives and livelihoods depend on them (Dressler et al. 2010).

Strengthening CBNRM is challenging; the myriad challenges of community-level management of social-ecological systems typify "wicked problems" (Game et al. 2014). However, the literature

\footnotetext{
${ }^{1}$ Social, Economic and Geographical Sciences Group, The James Hutton Institute, ${ }^{2}$ Sustainability Research Institute, School of Earth and the Environment and water@leeds, University of Leeds, ${ }^{3}$ Information and Computational Sciences Group, The James Hutton Institute, ${ }^{4}$ Pontificia Universidad Javeriana. School of environmental and rural studies. Department of Rural development, ${ }^{5}$ Faculty of Economics, National Autonomous University of Mexico (UNAM), ${ }^{6}$ Department of Economics, University of Birmingham, UK., ${ }^{7}$ Departamento de Antropología, Universidad de Buenos Aires, ${ }^{8}$ Instituto Argentino de Oceanografía - CONICET, ${ }^{9}$ Departamento de Geografía y Turismo, Universidad Nacional del Sur, ${ }^{10}$ Pontificia Universidad Javeriana-Faculty of Environmental and Rural Studies, ${ }^{11}$ Instituto Argentino de Oceanografía. Consejo Nacional de Investigaciones Científicas y Técnicas (IADO-CONICET), ${ }^{12}$ Universidad Nacional del Sur. Departamento de Geografía y Turismo, ${ }^{13}$ Fundación Aquamarina, Pinamar, ${ }^{14}$ Estudios Rurales y Asesoría Campesina (ERA), ${ }^{15}$ Departamento de Economía, Universidad Nacional del Sur, ${ }^{16}$ Instituto de Investigaciones Económicas y Sociales del Sur, ${ }^{17}$ Pontificia Universidad Javeriana, ${ }^{18}$ Instituto Argentino de Oceanografía - CONICET, Camino a la Carrindanga km 7, B8000BFW Bahía Blanca, Argentina, ${ }^{19}$ Departamento de Geología, Universidad Nacional del Sur, San Juan 670, B8000ICN Bahía Blanca, Argentina, ${ }^{20}$ Departamento de Geografía y Turismo - Universidad Nacional del Sur, ${ }^{21}$ Instituto de Investigaciones Económicas y Sociales del Sur (CONICET-UNS), ${ }^{22}$ Departamento de Economía, Universidad Nacional del Sur.
} 
has identified suggestions for how CBNRM might be improved or strengthened (Shackleton et al. 2010). We synthesize these into three interlinked needs: (1) to foster more meaningful participation of community members and their knowledges; (2) to develop adaptive capacity, i.e., the ability to consider and respond to present and future change; and (3) to adopt systems perspectives and understanding. Sustained meaningful participation requires community members to have input and control over planning and action for local social-ecological systems, as well as to have the opportunity and freedom to share knowledge and discuss and develop new ideas (Fabricus et al. 2004). This may be expected to facilitate the other two criteria; considering future change and proactive adaptation requires the ability to revisit and update plans, and a systems-thinking perspective implies an openness to thinking and discussion that recognizes multiple links between issues (Rogers et al. 2013), especially between components of ecological and social systems.

Although there is some agreement about what is needed to strengthen CBNRM, it is rather less clear which methods or techniques could achieve this (Shackleton et al. 2010). Authors have suggested a handful of approaches (e.g., Lynam et al. 2007), and among these, the idea of "scenario planning" has received some attention (e.g., Pert et al. 2010, Schreckenberg et al. 2010). We understand scenarios not as predictions, but as plausible and coherent descriptions of future states that can be used to explore possible consequences of decisions in a changing and uncertain world (Mietzner and Reger 2004). A wide variety of methods can be employed for scenario planning, although most share an emphasis on considering drivers of change, defined as factors that may strongly influence the focal system of concern (Rounsevell and Metzger 2010). Scenario planning has a long history of being used to identify, discuss, and tackle complex and emerging problems (Kahane and van der Heijden 2012). It is thought that it can help to foster creativity, dialogue, and use of different knowledges (Bengston et al. 2012), as well as explicit consideration of uncertainty, complexity, and the requirements for adaptation (Peterson et al. 2003, Wright and Goodwin 2009, Game et al. 2014).

These putative benefits match many of the needs for CBNRM identified previously. However, scenario planning is not a single well-defined method, and historically, its primary use has been in military and business settings (Bradfield et al. 2005). Therefore, our aim is to explore if and how scenario planning may support CBNRM. To do this, we designed and applied a scenario-planning method and evaluated experiences of its implementation using the following criteria: (1) Does it promote the ability to consider and respond to future change? (2) Does it encourage participation? (3) Does it support systems thinking?

\section{METHODS}

We describe the scenario-planning method, where and how it was implemented, and how we evaluated it. This investigation was the final phase of an action research project called "COMET-LA" (Community-Based Management of Environmental Challenges in Latin America; http://www.comet-la.eu). The project worked to explore and support CBNRM in three cases, in Argentina, Colombia, and Mexico (Fig. 1). For each case, implementation was facilitated by a project team containing an interdisciplinary mixture of researchers and case-specific civil society organization personnel, all based within the same country and with a prior history of working at the site.

The design of a scenario-planning method to support communitybased natural resource management

To create a scenario-planning method suitable to support CBNRM, we selected from a diverse set of existing examples (e.g., Wollenberg et al. 2000, Enfors et al. 2008) and reviews (e.g., van Notten et al. 2003, Börjeson et al. 2006). The overall method (Waylen et al. 2014) represents an innovative combination of preexisting techniques and ideas.

Our method contained 4 stages (Fig. 2). The first stage of the method explored how drivers of change could affect the system. Each team preselected drivers for presentation to the community by reviewing the drivers identified by a regional scenario-planning exercise for Latin America (The Millennium Project 2010) and selected 5 drivers to fit with the so-called STEEP typology, i.e., social, technological, environmental, economic, and policy (Bradfield et al. 2005). The selection was also informed by the teams' prior knowledge of the case system. The teams then specified 2 possible states for each driver, e.g., population may decline by $10 \%$, or increase by $10 \%$, informed by the latest statistics and trends reported for each country. This step was based on the literature because relying only on local perceptions to identify drivers may risk missing important drivers of change (e.g., Enfors et al. 2008). However, the drivers and their contrasting states were presented to the communities to modify or reselect.

Fig. 1. The location of the three cases in which the scenarioplanning method was implemented. More information about these cases is available in Table 1 and online (http://www.cometla.eu).

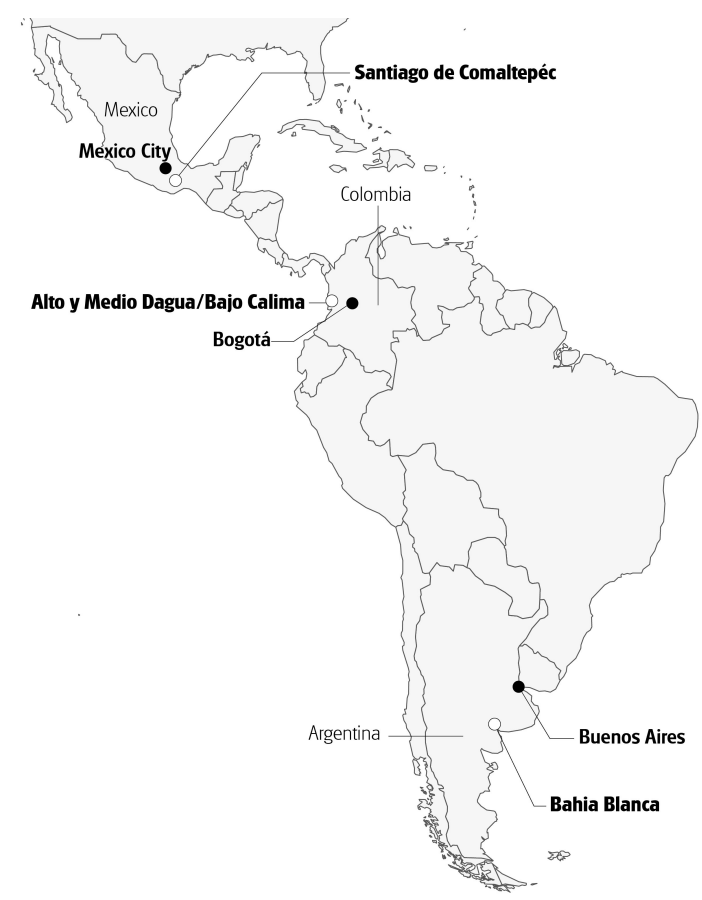


These 5 drivers were then used to explore potential system responses in the technique of "morphological analysis" (Godet 2006). This is the systematic description of a set of cause-andeffect relationships, structured and represented by a matrix. This technique was used, rather than the better known "2-axis" method popularized by the IPCC Special Report on Emissions Scenarios (Nakicenovic et al. 2000), because we wished to encourage consideration of a range of drivers and system variables rather than highlighting 2 drivers. It requires the social-ecological system to be described in terms of variables: for us, this was already available as each community had identified a list of variables representing key aspects of the local social-ecological system (Delgado Serrano et al. 2013), produced from previous project work informed by Ostrom (2009). The 5 drivers formed the top row of the matrix, and the system variables formed the side of the matrix. For each cell of the matrix, participants were asked what might happen to the system variable if the external driver takes a particular state, e.g., "what will happen to the forest condition if population increases or decreases by $10 \%$ ?" As an illustration, Appendix 1 provides an extract of one of the resulting matrices.

Fig. 2. The four stages of the scenario-planning method evaluated by this study.

Stage 1. Explore how drivers of change may influence the system, using 'morphological analysis'

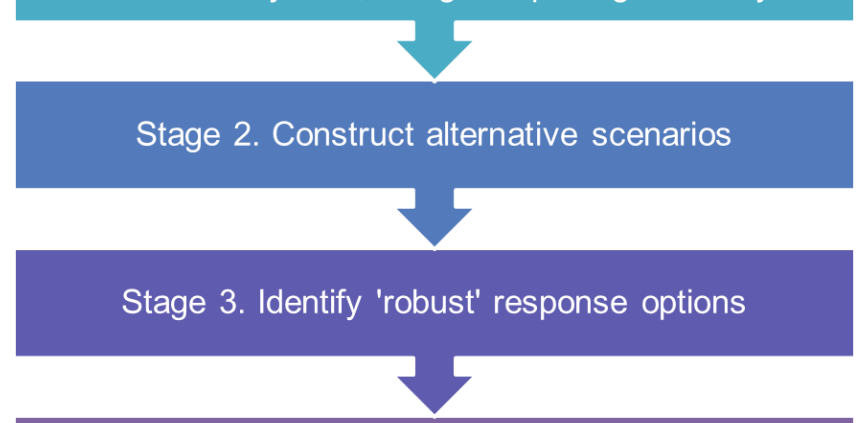

Stage 4. Discuss implications and requirements of response options

In the second stage, the contents of this matrix were used to inform the creation of alternative scenarios. There are many ways to combine cells from the matrix, so the use of "archetypes" was recommended as a helpful starting point and to assist in making the scenarios sufficiently distinct. Teams considered the six archetypes of Hunt et al. (2012), which contrast in multiple ways: for example, "eco-communalism" describes a world in which localism has been encouraged, whereas the "new sustainability paradigm" archetype arises from globalization. A plausible combination of cells from the matrix was used as the basis for creating narrative scenarios. These narratives were written descriptions of the future that encompass the future states and connections between drivers and social-ecological system variables. The narratives were extensively discussed and amended by community participants.
The third stage used these scenarios to provoke consideration of what actions, or response options, might be relevant to achieve community goals in light of possible future changes. These possible response options could include actions already within existing plans and programs or could be entirely new. After assembling a long list of possible response options, the notion of "robustness" was then discussed (Peterson et al. 2003). A robust response option was one that was deemed as both implementable and useful in more than one scenario. Options that were not robust were not further discussed.

In the fourth stage, the operational implications of the robust response options were discussed in more detail. Many examples of scenario planning in the literature provide more detail on scenario creation than on scenario utilization, so there was less guidance available as to how to structure these latter two stages. Each community differed in how it interpreted and carried out this final step, possibly reflecting the different pathways to implementation each was following by this stage. However, all groups discussed specifically what needed to be done, by when, and by whom, identifying specific actions for individuals, the community, and external actors to implement.

\section{Implementation of the scenario-planning method}

The method was implemented between March and July 2014 in the Argentinian, Colombian, and Mexican cases. Each case was experiencing challenges related to natural resource systems that are likely to be affected by climate change and other external drivers. Beyond this, the cases differed markedly in terms of their natural settings, socio-cultural context, and focal issues or goals (Table 1). Thus, they represent some of the diversity encompassed by the CBNRM label (Shackleton et al. 2010), and applying the method in all three cases allowed us to generate some common lessons.

Table 1 shows the actors engaged by the scenario-planning process: generally local residents and, less often, commercial or policy actors with power and influence over the system. In Mexico and Colombia, the participants were identified and recruited via preexisting community councils, whereas in Argentina participants were identified and recruited separately via stakeholder analysis. In Mexico and Colombia, separate meetings with some external actors such as officials from regional government provided these groups with information about the planning outputs and ideas, but liaison with these groups was not the main focus of the process. Hereafter, the local participants in each case are referred to as "communities," although we note that community is a complex concept (Waylen et al. 2013) and participation in this process is discussed within the findings presented subsequently.

Each team held at least three workshops to allow the community members to generate, amend, or validate previously generated data throughout the scenario-planning process; for logistical reasons, two cases chose to combine two stages into one workshop. Information on the workshops can be found in Table 2 .

\section{Data collection and analysis to evaluate the method}

We evaluated the implementation of scenario planning across the three cases in relation to benefits that may strengthen CBNRM. The introduction identified three factors as useful for 
Table 1. Description of the cases in which the scenario-planning method was implemented.

\begin{tabular}{|c|c|c|c|}
\hline Case & Argentina & Colombia & Mexico \\
\hline $\begin{array}{l}\text { System } \\
\text { boundaries and } \\
\text { scale }\end{array}$ & $\begin{array}{l}\text { Boundaries defined by project on the basis } \\
\text { of settlements adjacent to Monte Hermoso } \\
\text { Bahia Blanca estuary, along an E-W stretch } \\
\sim 100 \mathrm{~km} \text { in length. }\end{array}$ & $\begin{array}{l}\text { Official boundaries of Community } \\
\text { Councils (Consejo Communitarios) of Bajo } \\
\text { Calima and Alto y Medio Dagua ( } 77,724 \text { ha } \\
\text { and } 12,335 \text { ha). }\end{array}$ & $\begin{array}{l}\text { Official boundaries of community territory } \\
\text { of Santiago de Comaltepec, comprising } 3 \\
\text { settlements }(\sim 19,000 \text { ha). }\end{array}$ \\
\hline Natural setting & $\begin{array}{l}\text { Neotropic ecoregion, estuary (temperate } \\
\text { shelf and seas). }\end{array}$ & $\begin{array}{l}\text { Neotropic ecoregion, tropical and } \\
\text { subtropical moist broadleaf forest. }\end{array}$ & $\begin{array}{l}\text { Neotropic ecoregion, forest (ranging from } \\
\text { temperate forest to cloud forest). }\end{array}$ \\
\hline Protected areas & $\begin{array}{l}\text { Approximately } 210,000 \text {-ha estuarine } \\
\text { marshlands within Provincial Nature } \\
\text { Reserve Bahía Blanca, Falsa y Verde; } 1620 \text { - } \\
\text { ha Geological, Paleontological and } \\
\text { Archaeological Provincial Reserve Pehuén } \\
\text { co - Monte Hermoso; } 300 \text { ha within } \\
\text { Municipal Coastal Reserve. }\end{array}$ & $\begin{array}{l}\text { No protected areas, but Consejo } \\
\text { Communitarios have prohibited or } \\
\text { restricted certain uses, e.g., commercial } \\
\text { hunting and timber extraction without } \\
\text { license. }\end{array}$ & $\begin{array}{l}\text { Community has designated } \sim 500 \text { ha for } \\
\text { watershed protection, } \sim 2750 \text { ha for wildlife } \\
\text { protection, and } \sim 8450 \text { ha as a protected } \\
\text { forest reserve. }\end{array}$ \\
\hline $\begin{array}{l}\text { Main } \\
\text { livelihoods }\end{array}$ & $\begin{array}{l}\text { Fisheries, petrochemical industry, import/ } \\
\text { export activities linked to sea harbor and } \\
\text { tourism. }\end{array}$ & $\begin{array}{l}\text { Mining (legal and illegal), timber extraction } \\
\text { and processing, artisanal freshwater fishing, } \\
\text { illegal crops (coca), agriculture. }\end{array}$ & $\begin{array}{l}\text { Timber extraction, agriculture (swidden, } \\
\text { coffee, cattle) external remittances. }\end{array}$ \\
\hline $\begin{array}{l}\text { Community's } \\
\text { focal issue/goal }\end{array}$ & $\begin{array}{l}\text { To progress toward a more sustainable } \\
\text { management of the coastal and fisheries } \\
\text { resources for the local people and to } \\
\text { address together the pressure of external } \\
\text { agents. }\end{array}$ & $\begin{array}{l}\text { To achieve a sustainable management of } \\
\text { water and biodiversity, including the } \\
\text { decision of the communities and allowing } \\
\text { the improvement of the quality of life in the } \\
\text { territory. }\end{array}$ & $\begin{array}{l}\text { To achieve environmental and } \\
\text { socioeconomic sustainability through a use } \\
\text { of the forest that allows its current } \\
\text { conservation status while permitting the } \\
\text { community's youth to live and work locally, } \\
\text { keeping the culture and traditions of their } \\
\text { community-based governing system. }\end{array}$ \\
\hline $\begin{array}{l}\text { History of } \\
\text { community- } \\
\text { based natural } \\
\text { resource } \\
\text { management }\end{array}$ & $\begin{array}{l}\text { No prior experience of local collective } \\
\text { action. No formal community control in } \\
\text { processes of planning of coastal resources. }\end{array}$ & $\begin{array}{l}\text { Community control of territory and } \\
\text { collective planning since } 1993 \text {. Some } \\
\text { support from outside agencies/researchers. }\end{array}$ & $\begin{array}{l}\text { History of community control of territory } \\
\text { and planning of forest management since } \\
1970 \text { s. }\end{array}$ \\
\hline $\begin{array}{l}\text { Participating } \\
\text { stakeholders }\end{array}$ & $\begin{array}{l}\text { Local fishers, park rangers, a local } \\
\text { nongovernmental organization (NGO), } \\
\text { coast guards. }\end{array}$ & $\begin{array}{l}\text { Local people and their Consejo } \\
\text { Communitarios. }\end{array}$ & $\begin{array}{l}\text { Local people within the territory, } \\
\text { municipal authorities. }\end{array}$ \\
\hline $\begin{array}{l}\text { Other } \\
\text { stakeholders }\end{array}$ & $\begin{array}{l}\text { Local politicians, tourists and commercial } \\
\text { tourism operators, petrochemical industry, } \\
\text { port industry, government departments } \\
\text { relating to fisheries management. }\end{array}$ & $\begin{array}{l}\text { Guerrillas, illegal crop cultivators/traders, } \\
\text { the army, the environmental agency, } \\
\text { ministry of environment, NGOs, research } \\
\text { organizations. }\end{array}$ & $\begin{array}{l}\text { Environmental agency, NGOs, public forest } \\
\text { company. CONAFOR (National Forest } \\
\text { Commission). }\end{array}$ \\
\hline $\begin{array}{l}\text { Source of more } \\
\text { information }\end{array}$ & London et al. (2012) & Farah et al. (2012) & Escalante Semerena et al. (2012) \\
\hline
\end{tabular}

strengthening CBNRM. We converted these into criteria in our data collection and analysis. For the first factor, i.e., the ability to consider and respond to future change, we explored (1) if the teams were able to successfully facilitate community discussions about the future and (2) if this influenced ideas for useful future actions. For the second factor, i.e., participation and empowerment, we noted (1) the number and mix of community interests represented in discussions and (2) the effects of the process on community capacity for action and influencing other groups. For the third factor, i.e., systems thinking, we explored whether the process produced new recognition or insights about the connections between issues. However, during data collection and analysis, we aimed to avoid prejudging if and how the process had achieved influence. So, for example, we used open questions to solicit feedback about experiences of implementation.

If scenario planning is to benefit participation and systems thinking, as well as consideration of future change, the value of any method chosen is likely to depend as much on process, i.e., interactions and dialogue, as outputs, i.e., scenarios and response options. We therefore collected data on how the method was experienced through separate interviews with the teams facilitating the process in each case (Table 2). Therefore, the data reflect the views of the teams and not directly the views of the communities, although partly to address this, the lead authors observed one community workshop per case during the final stage of work in July 2014. These interviews were convened by videoconference subsequent to each workshop. A topic guide was used to probe experiences of implementing each stage (Appendix 2 ). As far as possible, the interviewers avoided prompting or prejudging opinions. These interviews were recorded and transcribed and were often supplemented by teams e-mailing written responses to further queries that arose from data analysis. Finally, in July 2014, the lead authors coordinated a cross-case workshop to discuss the teams' overall reflections and experiences of using this method. The notes of this discussion were also captured and transcribed.

Our analysis combined all these data, i.e., the results of implementing the method, the debriefing interviews on experiences of the process, and the cross-case workshop in July 2014. The software package Nvivo10 was used to store, manage, 
Table 2. The summary of the scenario-planning events and outputs in each case, as well as the main sources of information used to evaluate these experiences.

\begin{tabular}{|c|c|c|c|}
\hline Case & Argentina & Colombia & Mexico \\
\hline $\begin{array}{l}\text { Five drivers of } \\
\text { change: (a) social, } \\
\text { (b) technological, } \\
\text { (c) environmental, } \\
\text { (d) economic, and } \\
\text { (e) political }\end{array}$ & $\begin{array}{l}\text { (a) Changes in the size of human } \\
\text { population (regional), (b) weather forecasts } \\
\text { and navigation technology, (c) climate } \\
\text { change, (d) new entries of companies in the } \\
\text { harbor and intensification of dredging in } \\
\text { estuary, (e) changes in legislation of } \\
\text { economic activities and development of } \\
\text { environmental legislation. }\end{array}$ & $\begin{array}{l}\text { (a) Changes in the size of human } \\
\text { population (national), (b) infrastructure } \\
\text { megaprojects, (c) climate change, (d) } \\
\text { changes in commodities markets, (e) } \\
\text { changes in public policy, environmental } \\
\text { versus development focused. }\end{array}$ & $\begin{array}{l}\text { (a) Tightening/loosening migration } \\
\text { controls in the United States, (b) } \\
\text { technological change in timber harvesting } \\
\text { machinery, (c) climate change, (d) changes } \\
\text { in global market prices for timber products, } \\
\text { (e) political stability and changes in } \\
\text { property right systems. }\end{array}$ \\
\hline $\begin{array}{l}\text { Number of } \\
\text { scenarios created } \\
\text { and their names }\end{array}$ & $\begin{array}{l}3 \text { scenarios: "conventional world," "a new } \\
\text { paradigm of sustainability," and } \\
\text { "barbarization." }\end{array}$ & $\begin{array}{l}3 \text { scenarios: "stable future," "desirable } \\
\text { future," and "undesirable future." }\end{array}$ & $\begin{array}{l}5 \text { scenarios: "resources allocation," "policy } \\
\text { dominates," "sustainable social-ecological } \\
\text { system," "social entrepreneurialism," and } \\
\text { "chaotic world." }\end{array}$ \\
\hline $\begin{array}{l}\text { Number of final } \\
\text { response options } \\
\text { used in planning }\end{array}$ & 10 response options & $\begin{array}{l}4 \text { and } 5 \text { response options ( } 2 \text { groups } \\
\text { identified response options separately) }\end{array}$ & 11 response options \\
\hline $\begin{array}{l}\text { Main community } \\
\text { workshops for } \\
\text { scenario planning }\end{array}$ & $\begin{array}{l}\text { Stage } 1 \text { (April 2014), } \\
\text { stages } 2 \text { and } 3 \text { (May 2014), } \\
\text { stage } 4 \text { (July 2014). }\end{array}$ & $\begin{array}{l}\text { Stages } 1 \text { and } 2 \text { (April 2014), } \\
\text { stage } 3 \text { (May 2014), } \\
\text { stage } 4 \text { (July 2014). }\end{array}$ & $\begin{array}{l}\text { Stage } 1 \text { (March 2014), } \\
\text { stage } 2 \text { (May 2014), } \\
\text { stage } 3 \text { (May 2014), } \\
\text { stage } 4 \text { (June 2014). }\end{array}$ \\
\hline $\begin{array}{l}\text { Approximate } \\
\text { number of } \\
\text { participants in } \\
\text { workshops }\end{array}$ & 30 & 45 & 25 \\
\hline $\begin{array}{l}\text { Evaluation } \\
\text { interviews }\end{array}$ & $\begin{array}{l}3 \text { interviews: stage } 1 \text { postworkshop (May } \\
\text { 2014), stages } 2 \text { and } 3 \text { postworkshop (June } \\
\text { 2014), stage } 4 \text { postworkshop (July 2014). }\end{array}$ & $\begin{array}{l}3 \text { interviews: stages } 1 \text { and } 2 \text { postworkshop } \\
\text { (May 2014), stage } 3 \text { postworkshop (June } \\
\text { 2014), stage } 4 \text { postworkshop (July 2014). }\end{array}$ & $\begin{array}{l}4 \text { interviews: stage } 1 \text { postworkshop (April } \\
\text { 2014), stage } 2 \text { postworkshop (May 2014), } \\
\text { stage } 3 \text { postworkshop (June 2014), stage } 4 \\
\text { postworkshop (July 2014). }\end{array}$ \\
\hline $\begin{array}{l}\text { Evaluation } \\
\text { workshop }\end{array}$ & Cross-case workshop July 2014 & Cross-case workshop July 2014 & Cross-case workshop July 2014 \\
\hline $\begin{array}{l}\text { Main report of } \\
\text { outputs }\end{array}$ & Rojas et al. 2014 & Farah et al. 2014 & Escalante Semerena et al. 2014 \\
\hline
\end{tabular}

search, and deductively code these data using the criteria described previously. The themes we detected in the data are derived from all the previously mentioned sources but are illustrated using quotes from the interviews only. We focus on exploring whether the process produced benefits relevant to CBNRM. Therefore, in Findings, we do not describe the resulting outputs stage by stage for each case; this is already available in Escalante Semerena et al. (2014), Farah et al. (2014), and Rojas et al. (2014) and is synthesized in Martin-Ortega et al. (2014). Instead, we structure our findings according to the research objectives.

\section{FINDINGS}

All the cases were able to implement all four stages of the method. Furthermore, each team judged that doing so was worthwhile: the method could sometimes be demanding and required care to facilitate, but this effort was felt to be justified by the benefits delivered (Fig. 3). When we explored why the method was felt to be useful, each team reported a range of benefits, many of which appeared interconnected. A summary of the reported benefits in relation to our analytic criteria is presented in Table 3 . Subsequently, we discuss in detail if and how the method contributed to (1) considering future change, (2) fostering participation, and (3) supporting systems thinking.
Fig. 3. Judgments of the overall value of the scenario-planning method, as made by the team working in each case during an evaluation workshop in July 2014. Each team placed Post-it notes onto hand-drawn versions of the two axes, so as to show the usefulness of the overall method versus effort required. The stars represent the locations of the Post-it notes. Judgments about the individual steps of the method were also recorded and are available from the authors upon request.

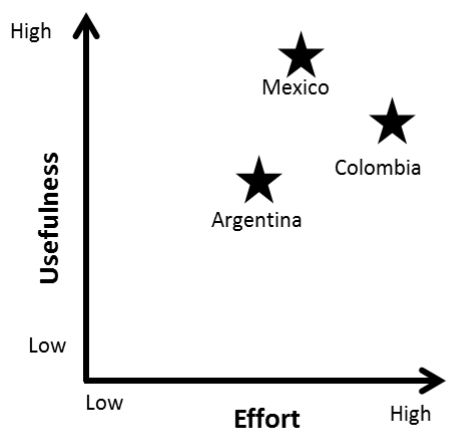


Table 3. Summary evaluation of scenario-planning method, assessed for each case in relation to criteria relevant to strengthening community-based natural resource management (CBNRM).

\begin{tabular}{|c|c|c|c|c|}
\hline $\begin{array}{l}\text { Benefit Relevant } \\
\text { to CBNRM }\end{array}$ & Criterion & Argentina & Colombia & Mexico \\
\hline \multirow[t]{2}{*}{$\begin{array}{l}\text { Ability to } \\
\text { consider and } \\
\text { respond to future } \\
\text { change }\end{array}$} & $\begin{array}{l}\text { Discussions about } \\
\text { future change }\end{array}$ & $\begin{array}{l}\text { Yes. Need to consider future } \\
\text { change accepted, from stage } 1 \text {, and } \\
\text { ideas for future scenarios } \\
\text { generated, from stage } 2 \text {. }\end{array}$ & $\begin{array}{l}\text { Yes. Need to consider future } \\
\text { change accepted in stage } 1 \text { and } \\
\text { ideas for future scenarios generated } \\
\text { in stage } 2 \text {. }\end{array}$ & $\begin{array}{l}\text { Yes. Need to consider future change } \\
\text { accepted in stage } 1 \text { and ideas for } \\
\text { future scenarios generated in stage } 2 \text {. }\end{array}$ \\
\hline & $\begin{array}{l}\text { Generation of ideas } \\
\text { for robust actions }\end{array}$ & $\begin{array}{l}\text { Yes. Several potential new actions } \\
\text { identified as robust in stage } 3 \text {. }\end{array}$ & $\begin{array}{l}\text { Yes. Several potential actions } \\
\text { identified as robust in stage } 3 \\
\text { (mainly drawing on existing plans). }\end{array}$ & $\begin{array}{l}\text { Yes. Several potential actions } \\
\text { identified as robust in stage } 3 \text {. }\end{array}$ \\
\hline \multirow[t]{2}{*}{$\begin{array}{l}\text { Community } \\
\text { participation }\end{array}$} & $\begin{array}{l}\text { Representation of } \\
\text { different interests } \\
\text { from within the } \\
\text { community }\end{array}$ & $\begin{array}{l}\text { Yes. Formation of new community } \\
\text { group and commitment to work } \\
\text { together, arising from whole } \\
\text { process. New use of social media to } \\
\text { maintain links between local } \\
\text { people. }\end{array}$ & $\begin{array}{l}\text { Yes. Broad though incomplete } \\
\text { representation of interests within } \\
\text { the community, widening at final } \\
\text { stage. }\end{array}$ & $\begin{array}{l}\text { Partial. Small gains made in } \\
\text { increasing women's representation, } \\
\text { arising from whole process. }\end{array}$ \\
\hline & $\begin{array}{l}\text { Community influence } \\
\text { in, and recognition } \\
\text { by, other governance } \\
\text { forums }\end{array}$ & $\begin{array}{l}\text { Yes. New provincial law passed to } \\
\text { recognize rights of artisanal fishers, } \\
\text { partially spurred by this project, } \\
\text { subsequent to close of process. }\end{array}$ & $\begin{array}{l}\text { Partial. Community recognized } \\
\text { need to engage with higher-level } \\
\text { statutory processes, arising from } \\
\text { stages } 3 \text { and } 4 \text {; already had formal } \\
\text { legal standing and territorial } \\
\text { control. }\end{array}$ & $\begin{array}{l}\text { No. No effect on community } \\
\text { recognition in other forums, partly } \\
\text { because they already had formal } \\
\text { legal standing and territorial } \\
\text { control. }\end{array}$ \\
\hline Systems thinking & $\begin{array}{l}\text { Identification of new } \\
\text { connections between } \\
\text { issues }\end{array}$ & $\begin{array}{l}\text { Yes. New recognition of how } \\
\text { aspects of the social-ecological } \\
\text { systems are linked, arising from all } \\
\text { stages of the process but especially } \\
\text { the morphological analysis in stage } \\
1 \text { and the discussion of response } \\
\text { options in stage } 4 \text {. }\end{array}$ & $\begin{array}{l}\text { Yes. New recognition of how } \\
\text { aspects of the social-ecological } \\
\text { system are linked, arising from all } \\
\text { stages of the process but especially } \\
\text { the morphological analysis in stage } \\
1 \text { and the discussion of response } \\
\text { options in stage } 4 \text {. }\end{array}$ & $\begin{array}{l}\text { Yes. New recognition of how aspects } \\
\text { of the social-ecological system are } \\
\text { linked, arising from all stages of the } \\
\text { process but especially the } \\
\text { morphological analysis in stage } 1 .\end{array}$ \\
\hline
\end{tabular}

\section{Did the method promote the ability to consider and respond to future change?}

The most obvious expectation for scenario planning is that it will encourage consideration of the future. This indeed occurred in all cases, although careful facilitation was needed to assist people to look beyond immediate concerns. This was often achieved by discussing past changes and the drivers that had caused these. Climate change was the most easily introduced concept, whereas other drivers, i.e., policy change, required more discussion and sometimes adjustment before the communities considered them salient. However, once people were engaged in thinking beyond the status quo, many ideas about the future were produced, and the need to plan now for future change was recognized. The detail and complexity of future visions and responses was evidenced throughout the copious outputs and discussion notes produced from the workshops in each country. For example, robust response options generated by Argentina, Mexico, and Colombia ranged from tackling corruption to developing ethnic education curricula and changing forest management techniques.

By the end of the process, a range of drivers, not only climate change, were seen as important in shaping possible scenarios and therefore community responses. For example, Mexican participants identified emigration as a critical driver shaping the local system and so decided that promoting "territorial identity" would be a robust response option because they saw community cohesion as a critical asset that could not be taken for granted.

Looking at a time horizon of twenty years enabled participants to perform an exercise in perspective in a country where there are no political agendas in twenty years ... and another very important thing of this method is that, having done this exercise at twenty years' sight, directly or indirectly, each stakeholder revealed themselves as responsible. (Argentina team, interview on stage 1)

The previous quote illustrates how communities' discussions about the future often highlighted the role of different individuals and organizations in managing the natural system. This seems to have resulted from stages 3 and 4, so the method ensured attention was given to discussing how to use the scenarios for planning responses. This topic often spontaneously led to a discussion on responsibilities and the need "to work together for a better future" (Argentina team, interview on stages 2 and 3). This is particularly noteworthy in the case of Argentina because these participants previously lacked a strong sense of community nor had a formal community-based organization to represent them. Thus, discussions of response options were particularly interconnected with the topics of participation and empowerment.

\section{Did the method foster participation?}

In all cases, the method provided a new opportunity for discussion between community members, thus widening participation in collective deliberation and decision making. All three teams tried to foster widespread engagement with the method and communicate that it was intended to assist the communities to achieve their own goals. However, the process does not claim to have perfectly empowered all community members, not least because many of the team members were based outside the communities. 
The biggest efforts to empower community members were made in Colombia, where the team trained "coinvestigators" from the community to broaden participation within and between the workshops that were the main formal spaces for engagement. This meant a large and diverse set of voices participated in the process. Some limitations on participation related to preexisting conflicts or differences of opinion within the community. For example, even the coinvestigators could not easily engage one subgroup that did not wish to participate, though some individuals from this attended the final workshops, incorporating new points of view. In Argentina, the project brought together a set of local people with different interests for the first time, although participation was limited by factions between different fishers and the lack of engagement by more powerful actors, e.g., national and multinational corporations operating in the area. In Mexico, preexisting social norms meant that those engaged tended to be older men linked to the existing community governing body. A single project cannot overturn such norms, but it did achieve some influence: by the end of the process, a woman rose for the first time to speak publicly in a workshop, and beyond the workshops other women requested roles in formal decision making.

In all three cases, the method raised issues about representation. In Mexico, it provoked a reexamination of who from within the communities is represented within such forums, whereas in Colombia it prompted a discussion about the need for the community to be represented in higher-level statutory planning processes. Perhaps the greatest gains to representation have been made in Argentina, which began with no clearly defined or formally recognized community. Here the process has helped participants to strengthen their own idea of community and to initiate collective discussions. In addition, a new provincial law named Ley de Pesca Artesanal de la Provincia de Buenos Aires was passed in May 2015. This law helps to protect and manage artisanal fisheries (Schwerdt 2015): it was created directly as a result of the lobbying action of the artisanal fishers involved in this project ("Presentan proyecto de reforma a la Ley de Pesca Artesanal que rige en Rio Negro" 2015), and they have credited the project as one of the factors that galvanized their actions (Eduardo Flores, personal communication). Artisanal fisheries are typically lower impact than visiting trawler fleets, so it is hoped that this law has empowered local fishers to maintain a more sustainable use of the coastal resources.

Discussions between community members provided an opportunity to share ideas about the local system variables, drivers of future change, and possible responses. These discussions mostly relied on existing local knowledge because external knowledge was only formally introduced via the drivers of change proposed to the communities at the start of stage 1 . The collective production and evolution of new ideas from discussions is therefore suggestive of social learning. For example, during stages 3 and 4 of the method, the Colombian participants decided on a new goal, to network and coordinate with other Community Consejos, to learn from each other, and to have more influence in regional-level statutory processes. Because the individuals in the Colombian case already had a history of working together, it might have been expected that they would not identify any new ideas: this suggests something in the method itself, beyond providing another opportunity to meet, was useful in facilitating social learning.

\begin{abstract}
You can perceive that they are a little bit more ... uh ... aware that they have a lot of vulnerabilities and that they have to be even stronger nowadays than maybe what they thought a few years ago, because the context is not easy. So ... maybe new knowledge, like any new idea or anything ... like that hasn't been taken into account never before, maybe not. But you can feel that they have been changing their ... like their expectations and what they are hoping to be in the future has forced them to do that. (Colombia team, interview on stage 3)
\end{abstract}

Every community identified several actions that would help build community resilience to future change. In all cases, these included both actions that the community could undertake and identification of how the community might need to liaise with or receive support from external actors. For example, the Mexican community decided it needed greater input into municipal-level planning processes, as well as creating its own local-level management plan. As noted previously, the need to work with or lobby higher-level statutory bodies was also identified in the Colombian case. In Argentina, the participants have no formal recognition as a community, nor have they rights to influence decision making affecting coastal resources, but they identified social media as a future means to communicate and organize for future collective action. This suggests that in all cases the process has supported community members to plan and act together.

\section{Did the method support systems thinking?}

From stage 1, there were indications that implementing the method was aiding the communities, as well as the teams, to develop a systems-thinking perspective. Across all the cases, teams reported that community members became more aware of the connections between issues because the method pushed them to consider a wide range of linkages. This was manifest through discussions on specific connected issues, but also through a more general shift in perspective. For example, during the interview to discuss stage 2 in Mexico, the team described some community members as "able now see the film: before they had only a few scenes." By this we understand that participants achieved a shift in perspective to consider how multiple environmental aspects of the society and environment were intertwined and affected by drivers, instead of focusing on specific issues.

Teams often found it difficult to detect or describe exactly when and how systems thinking arose during the scenario-planning process. Furthermore, it was difficult to disentangle the effect of the scenario planning from other influences. As the Argentina team put it, this was "one of the processes which ... helped stakeholders to re-think" (Argentina team, interview on stage 1). However, the consideration of detailed linkages between drivers and variables during the morphological analysis, and the use of the resulting matrix, was reported as one aspect of the method that definitely helped develop a systems-thinking perspective. For example, the Mexico team described that this activity "enabled us to find the complexity of relationships. This is the central issue: obviously, for systems of this nature, with these characteristics, linearities are very scarce" (Mexico team, report on stage 1 in the evaluation workshop). 
The reason that the morphological analysis was helpful for promoting a systems perspective seemed related to its systematic nature. By "systematic," we mean an approach that ensures that each and every issue and potential interconnection is considered in turn. Morphological analysis is systematic because it requires discussion to decide how to fill every cell of a matrix of drivers and system variables. The Colombian team reported that "the matrix was very useful for the systems thinking, because you are not only talking about one little aspect of the system but the integrity of all of them and also the drivers of change ... putting one issue related to another" (Colombia team, interview on stages 1 and 2).

The discussion of the response options also aided a thorough consideration of relationships and system interconnections. In this stage, attention tended to focus on the interconnections between and within existing societal and governance systems.

The workshop allowed the participants to imagine the possible networks that might emerge during the implementation of the response options, by identifying the actors potentially involved. Finally, the variety of the response options revealed systems thinking, not only because all the main issues of the community are addressed, but also because the response options are somehow related to each other and their achievement is expected to generate synergies. (Colombia team, interview on stage 3 , describing the benefits to systems thinking generated by the workshop to discuss response options)

Carefully thinking through the responses needed was important for "grounding" discussion, encouraging community members to move beyond aspiration and toward detailed practical planning, and toward identifying who would do what and when. For example, when the Mexican community discussed response options, they identified that they wished to reduce dependence on timber harvesting through livelihood diversification. They noted that this requires financial investment among other things and that this in turn this requires changes in existing financial institutions and rules governing economic activities. A clear sequence of events is established, each entailing support by a different set of actors. These discussions often highlighted the need for involvement from many external actors beyond the community to facilitate priority response options. For example, changing and improving local education curricula was prioritized in all three cases but would require support or commitment from national governments.

\section{DISCUSSION}

The experiences of this scenario-planning method suggest that it generated several benefits relevant to supporting CBNRM. Our evaluation found indications that the method helped consideration of future change, fostered community participation and knowledge sharing, and encouraged systems thinking in three very different cases. We briefly review these effects in relation to other studies, before discussing implications for future research and practice.

We believe the process strengthened participation because it encouraged collective dialogue that highlighted issues of representation within or beyond the community, and this resulted in communities identifying and beginning to implement actions. Although this is still far from some ideals of perfect empowerment, it goes beyond the limited "consultation" observed in many CBNRM projects (Shackleton et al. 2010). We therefore conclude that scenario planning should be considered among other tools that have the potential to help engage and even empower community members (Richards et al. 2007). The scenario-planning process did require careful facilitation, so we agree that facilitation is a crucial factor influencing the success of any tool used to support CBNRM (Hagmann et al. 2002).

The observation that scenario planning can help its participants consider the future is unsurprising because the method revolves around discussing the future. However, it is worth confirming because there is often concern that it can be difficult for people to look beyond immediate issues and concerns (Moser 2010), even though consideration of future change is a necessary prerequisite if CBNRM is to be more adaptive (Armitage 2005). Climate change now seems widely recognized, albeit its implications for current planning and decision making are not often understood (Farrell 2010), whereas other drivers of change, such as policy or market change, are often given much less attention. We show it is possible to consider a range of types of drivers, not only climate change, in ways that allow communities to plan how to adapt and respond.

The method's reported effects on systems thinking were most striking. This is particularly valuable because few examples of CBNRM can demonstrate consideration of multiple issues and connections, and there are few approaches known to enable systems thinking (Best and Holmes 2010). The focus on the relatively distant future may be particularly helpful in allowing participants to "open up" or reframe to consider new ways of thinking (Peterson et al. 2003) and may explain the effects on systemic or holistic thinking reported for this and some other scenario-planning initiatives (e.g., Greeuw et al. 2003, as cited in Peterson et al. 2003, Beach and Clark 2015). Our evaluation also suggested that systems thinking was particularly likely to be associated with the parts of the method that required a systematic approach.

Of course, a single episode of scenario planning will not, by itself, ensure the sustained iterative and inclusive approach that is necessary for adaptive management of complex systems. However, the findings of our evaluation suggest that scenario planning should be considered as something that might assist in this, as we discuss subsequently.

Implications for community-based natural resource management Our experiences provide cautious support for using scenario planning to support CBNRM in other situations. However, careful attention to detail is required. It is important to use a method that compels a systematic approach to considering a wide range of potential interactions between issues. We used morphological analysis (Godet 2006) to structure the discussion of how drivers affect variables. This may be useful in other cases, although it can be onerous to carry out and requires aspects of systems to be described in terms of variables. Furthermore, our method balanced attention to creating scenarios with the aim of 
giving space to consider new ideas, with attention to using scenarios, and with the aim of identifying practical implications for current plans. Discussion around response options seemed particularly useful for helping participants move beyond vague aspirations and to identify tangible actions for themselves and others. Therefore, we suggest that a process that focuses mainly on creating scenarios would likely realize fewer benefits.

Discussions of response options highlighted the need for actors beyond the community to support or facilitate local-level initiatives. However, because this was a process that was designed primarily to engage community members, those external actors may have little awareness of, or any commitment to, the response options that communities wish to prioritize. The reliance on local knowledge may weaken the external credibility of its outputs, as well as missing opportunities to use scientific knowledge to enrich local understandings of the social-ecological system. Therefore, we question the extent to which this, or indeed any process focused solely on community participation and knowledges, can support and strengthen CBNRM when local systems are affected by external actors (Ostrom and Cox 2010). Because multilevel governance is the norm rather than the exception (e.g., Mwangi and Wardell 2012), "pure" CBNRM may not always be the most suitable approach (Armitage 2005). In future, it may be fruitful to explore whether other actors and other sources of knowledge (e.g., Mistry et al. 2014) can be incorporated without jeopardizing community participation and empowerment.

If new initiatives implement any type of scenario-planning method, it will be important to track and evaluate them, as discussed previously, to provide more evidence as to if and how scenario planning may support CBNRM. Thus, we turn to implications for future research.

\section{Recommendations for future research}

We recommend that scenario planning be considered by those seeking to implement or strengthen CBNRM and indeed anyone seeking to promote systemic, participatory, and adaptive management of social-ecological systems. However, this was an initial exploratory investigation of the benefits that scenario planning can bring, and many questions remain.

First, we have reported only on experiences of trying to implement one particular method for scenario planning, but many other options are available (van Notten et al. 2003). Some may not suit many CBNRM contexts, e.g., have demanding computational needs, but other options may appear difficult to choose between. Therefore, it would be useful for comparative research or reviews to identify which other methods might be relevant. New guidance is also needed as to how to use scenarios to elicit response options to inform planning and management.

In particular, we were not able to confirm the extent to which systems thinking was fostered by the process and determine exactly when and how these effects arose. Systems thinking is not something easily measured. However, some prior work has considered its basis (e.g., Checkland 1999), and a larger body of work on project evaluation (e.g., Stem et al. 2005) indicates that a mix of methods could be useful to explore the phenomenon. These could range from ethnographic observation to multicriteria decision analysis. Whatever the methods used, a longitudinal approach will be needed to study a process before, during, and after any specific intervention and to take account of external influences on effects ascribed to scenario planning. Given the reported difficulties of systems thinking (Best and Holmes 2010), yet its necessity to managing social-ecological systems (Rogers et al. 2013), this is a particularly urgent research priority.

Monitoring the effects of scenario planning should continue after a specific intervention ends. For example, we have been able to report on outcomes that have arisen a year after the method was implemented, i.e., the 2015 Argentinean law for artisanal fisheries reported previously. This helped substantiate claims that the method supported participation and empowerment, yet our formal period of data collection ended in 2014. Each case is currently exploring other response options, so further effects may yet arise. Long-term monitoring is required to judge exactly if and how a process has galvanized local action and adaptation (Lindenmayer and Likens 2009).

It would also be helpful if future approaches to evaluation were applied to other tools and methods, not only scenario planning. This would allow a comparative approach that would identify the strengths and weaknesses of scenario planning versus other methods (Lynam et al. 2007). For example, some of the effects on participation and empowerment that we observed might be expected of other methods in which facilitators repeatedly, carefully, and respectfully encouraged and recorded community dialogue (Reed 2008). Therefore, scenario planning may not be necessary if participation is the main benefit being sought; however, other methods might struggle to handle future change or systems thinking. Understanding the pros and cons of different methods in different contexts is important, so that those seeking to improve resource management may make informed choices.

\section{CONCLUSION}

We suggest that scenario planning has the potential to support CBNRM by building capacity for consideration of future change, facilitating participation and empowerment, and fostering systems thinking. However, achieving these benefits depends on details of the method chosen, as well as careful facilitation. In particular, we suggest that a systematic approach to considering interconnections between a wide set of topics can help to foster systems thinking and consideration of new issues. Second, it is useful for a process to focus attention on how to use scenarios, rather than focusing solely on creating the scenarios themselves. However, to fully understand how such benefits may be produced, particularly for systems thinking, future research is needed to track the processes and effects of other scenario-planning initiatives. Because community actions and adaptation often require support from others, it may also be useful to consider whether external actors could participate in scenario planning, to connect with existing multilevel governance processes and build on externally validated evidence. In the interim, because our method was judged as worthwhile in three very different socialecological systems, we suggest that this may provide a useful starting point for others interested in participatory scenario planning for CBNRM. 
Responses to this article can be read online at: http://www.ecologyandsociety.org/issues/responses. $\mathrm{php} / 7926$

\begin{abstract}
Acknowledgments:
The research leading to these results received funding from the European Union's Seventh Framework Programme (FP7/2007-2013) under grant agreement no. 282845 for project COMET-LA and was also partly funded by the Rural and Environment Science and Analytical Services Division of the Scottish Government. We thank the community members of the Mexican, Argentinean, and Colombian cases, whose enthusiasm and willingness to engage made this work possible.
\end{abstract}

\section{LITERATURE CITED}

Armitage, D. 2005. Adaptive capacity and community-based natural resource management. Environmental Management 35 (6):703-715. http://dx.doi.org/10.1007/s00267-004-0076-z

Beach, D. M., and D. A. Clark. 2015. Scenario planning during rapid ecological change: lessons and perspectives from workshops with southwest Yukon wildlife managers. Ecology and Society 20 (1):61. http://dx.doi.org/10.5751/es-07379-200161

Bengston, D. N., G. H. Kubik, and P. C. Bishop. 2012. Strengthening environmental foresight: potential contributions of futures research. Ecology and Society 17(2):10. http://dx.doi. org/10.5751/ES-04794-170210

Best, A., and B. Holmes. 2010. Systems thinking, knowledge and action: towards better models and methods. Evidence \& Policy: A Journal of Research, Debate and Practice 6(2):145-159. http:// dx.doi.org/10.1332/174426410X502284

Börjeson, L., M. Höjer, K.-H. Dreborg, T. Ekvall, and G. Finnveden. 2006. Scenario types and techniques: towards a user's guide. Futures 38(7):723-739. http://dx.doi.org/10.1016/j.

futures.2005.12.002

Bradfield, R., G. Wright, G. Burt, G. Cairns, and K. Van Der Heijden. 2005. The origins and evolution of scenario techniques in long range business planning. Futures 37(8):795-812. http://dx. doi.org/10.1016/i.futures.2005.01.003

Checkland, P. 1999. Systems thinking. Pages 45-56 in W. Currie and B. Galliers, editors. Rethinking management information systems. Oxford University Press, Oxford, UK.

Delgado Serrano, M. M., P. Ramos, A. Nekhay, P. Vanwildemeersch, P. Ambrosio, C. Riccioli, R. Navarro, J. Berbel, and J. Icely. 2013. D1.1. Locally-adapted tools for the characterization of social-ecological-systems. Deliverable 1.1 of the project COMET-LA (Community-Based Management of Environmental Challenges in Latin America), University of Cordoba, Cordoba, Spain. [online] URL: http://www.comet-la. eu/images/comet la/deliverebles/COMET-LA\%20D1.1.pdf

Dressler, W., B. Büscher, M. Schoon, D. Brockington, T. Hayes, C. A. Kull, J. McCarthy, and K. Shrestha. 2010. From hope to crisis and back again? A critical history of the global CBNRM narrative. Environmental Conservation 37(1):5-15. http://dx.doi. org/10.1017/s0376892910000044

Enfors, E. I., L. J. Gordon, G. D. Peterson, and D. Bossio. 2008. Making investments in dryland development work: participatory scenario planning in the Makanya catchment, Tanzania. Ecology and Society 13(2):42. [online] URL: http://www.ecologyandsociety. org/vol13/iss2/art42/

Escalante Semerena, R. I., S. Basurto Hernández, S. I. Brugger Jakob, Y. Lara Padilla, F. Chapela, and I. Hernández López. 2012. Deliverable D3.1: stakeholders' vision on the socio-ecological system (SES) situation in Mexico. A case study. Deliverable 3.1 of the project COMET-LA (Community-Based Management of Environmental Challenges in Latin America), Universidad Nacional Autónoma de México (UNAM), Mexico City, Mexico. [online] URL: http://www.comet-la.eu/images/comet_la/deliverebles/ D\%203.1. Comaltepec.pdf

Escalante Semerena, R. I., S. Basurto Hernández, I. Hernández López, and A. R. Marneau Acevedo. 2014. D3.3: stakeholder visions and perspectives on the future from the Santiago Comaltepec case study in Mexico. Deliverable 3.3 of the project COMET-LA (Community-Based Management of Environmental Challenges in Latin America), Universidad Nacional Autónoma de México (UNAM), Mexico City, Mexico. [online] URL: http://www. comet-la.eu/images/comet la/deliverebles/Deli 3.3.pdf

Fabricus, C., E. Koch, S. Turner, and H. Magome, editors. 2004. Rights resources and rural development: community-based natural resource management in Southern Africa. Earthscan, London, $\mathrm{UK}$.

Farah, M. A., E. Garrido, D. L. Maya, C. Ortiz, and P. Ramos. 2012. Deliverable D2.1: stakeholder vision on the socio-ecological system situation in Colombia case study. Deliverable 2.1 of the project COMET-LA (Community-Based Management of Environmental Challenges in Latin America), Pontificia Universidad Javeriana, Bogotá, Colombia. [online] URL: http:// www.comet-la.eu/images/comet la/deliverebles/D $\% 202.1$.stakeholder $\%$ 20view $\% 20$ on $\% 20$ SES $\% 20$ deliverable $\% 20$ COLOMBIA $\% 2014 \% 20$ SEPT $\%$ 202012\%20final.pdf

Farah, M. A., D. L. Maya, C. Ortiz, N. Ocampo, B. Avendaño, L. Pinzon, and P. Ramos. 2014. D2.3: stakeholder vision on perspectives for the future in the Colombia case study. Deliverable 2.3 of the project COMET-LA (Community-Based Management of Environmental Challenges in Latin America), Pontificia Universidad Javeriana, Bogotá, Colombia. [online] URL: http:// www.comet-la.eu/images/comet la/deliverebles/Deli 2.3.pdf

Farrell, L. A. 2010. Mainstreaming climate change adaptation into urban development: lessons from two South African cities. Thesis. Massachusetts Institute of Technology, Cambridge, Massachusetts, USA.

Game, E. T., E. Meijaard, D. Sheil, and E. McDonald-Madden. 2014. Conservation in a wicked complex world: challenges and solutions. Conservation Letters 7(3):271-277. http://dx.doi. org/10.1111/conl.12050 
Godet, M. 2006. Creating futures. Scenario planning as a strategic management tool. Economica, Paris, France.

Hagmann, J. R., E. Chuma, K. Murwira, M. Connolly, and P. Ficarelli. 2002. Success factors in integrated natural resource management R\&D: lessons from practice. Conservation Ecology 5(2): 29. [online] URL: http://www.consecol.org/vol5/iss2/art29

Haller, T., M. Galvin, P. Meroka, J. Alca, and A. Alvarez. 2008. Who gains from community conservation? Intended and unintended costs and benefits of participative approaches in Peru and Tanzania. Journal of Environment \& Development 17 (2):118-144. http://dx.doi.org/10.1177/1070496508316853

Hunt, D. V. L., D. R. Lombardi, S. Atkinson, A. R. G. Barber, M. Barnes, C. T. Boyko, J. Brown, J. Bryson, D. Butler, S. Caputo, M. Caserio, R. Coles, R. F. D. Cooper, R. Farmani, M. Gaterell, J. Hale, C. Hales, C. N. Hewitt, L. Jankovic, I. Jefferson, J. Leach, A. R. MacKenzie, F. A. Memon, J. P. Sadler, C. Weingaertner, J. D. Whyatt, and C. D. F. Rogers. 2012. Scenario archetypes: converging rather than diverging themes. Sustainability 4 (4):740-772. http://dx.doi.org/10.3390/su4040740

Kahane, A., and K. van der Heijden. 2012. Transformative scenario planning: working together to change the future. BerrettKoehler, San Francisco, California, USA.

Lindenmayer, D. B., and G. E. Likens. 2009. Adaptive monitoring: a new paradigm for long-term research and monitoring. Trends in Ecology \& Evolution 24(9):482-486. http://dx.doi.org/10.1016/ j.tree.2009.03.005

London, S., M. Recalde, and M. Rojas. 2012. Stakeholder vision on the social-ecological-system situation in Argentina case study. Deliverable 4.1 of the project COMET-LA (Community-Based Management of Environmental Challenges in Latin America), Universidad Nacional del Sur, Bahía Blanca, Argentina. [online] URL: http://comet-la.eu/images/comet la/deliverebles/D\%204.1. DELIVERABLE\%20ARGENTINA\%20FINAL.pdf

Lynam, T., W. De Jong, D. Sheil, T. Kusumanto, and K. Evans. 2007. A review of tools for incorporating community knowledge, preferences, and values into decision making in natural resources management. Ecology and Society 12(1):5. [online] URL: http:// www.ecologyandsociety.org/vol12/iss1/art5/

Martin-Ortega, J., K. Waylen, J. P. Martin-del-Molino, K. Blackstock, and I. Brown. 2014. D5.1: participatory report on synthesised scenarios: summary and comparison of the scenario building processes and outcomes in the three case studies. Deliverable 5.1 of the project COMET-LA (Community-Based Management of Environmental Challenges in Latin America), James Hutton Institute, Aberdeen, UK. [online] URL: http:// www.comet-la.eu/images/comet la/deliverebles/Deli 5.1.pdf

Méndez-López, M. E., E. García-Frapolli, D. J. Pritchard, M. C. Sánchez González, I. Ruiz-Mallén, L. Porter-Bolland, and V. Reyes-Garcia. 2014. Local participation in biodiversity conservation initiatives: a comparative analysis of different models in South East Mexico. Journal of Environmental Management 145:321-329. http://dx.doi.org/10.1016/j. jenvman.2014.06.028
Mietzner, D., and G. Reger. 2004. Scenario approaches - history, differences, advantages and disadvantages. Pages 48-62 in Proceedings of the EU-US Scientific Seminar: New Technology Foresight, Forecasting \& Assessment Methods (Seville, Spain, 13-14 May 2004). Joint Research Centre, European Commission, Seville, Spain. [online] URL: http://foresight.jrc.ec.europa.eu/fta/ papers/Session $\% 201 \% 20$ Methodological $\% 20$ Selection $/$ Scenario $\%$ 20Approaches.pdf

The Millennium Project. 2010. Futures studies around the world: Latin America 2030. In J. C. Glenn, T. J. Gordon, and E. Florescu, editors. 2010 State of future [CD-ROM]. The Millennium Project of the American Council for the United Nations University, Washington, D.C., USA.

Mistry, J., C. Tschirhart, C. Verwer, R. Glastra, O. Davis, D. Jafferally, L. Haynes, R. Benjamin, G. Albert, R. Xavier, I. Bovolo, and A. Berardi. 2014. Our common future? Cross-scalar scenario analysis for social-ecological sustainability of the Guiana Shield, South America. Environmental Science \& Policy 44:126-148. http://dx.doi.org/10.1016/j.envsci.2014.05.007

Moser, S. C. 2010. Communicating climate change: history, challenges, process and future directions. Wiley Interdisciplinary Reviews: Climate Change 1(1):31-53. http://dx.doi.org/10.1002/ $\underline{\text { wcc. } 11}$

Mwangi, E., and A. Wardell. 2012. Multi-level governance of forest resources (editorial to the special feature). International Journal of the Commons 6(2):79-103.

Nakicenovic, N., J. Alcamo, G. Davis, B. de Vries, J. Fenhann, S. Gaffin, K. Gregory, A. Grübler, T. Yong Jung, T. Kram, E. Lebre La Rovere, L. Michaelis, S. Mori, T. Morita, W. Pepper, H. Pitcher, L. Price, K. Riahi, A. Roehrl, H.-H. Rogner, A. Sankovski, M. Schlesinger, P. Shukla, S. Smith, R. Swart, S. van Rooijen, N. Victor, and Z. Dadi. 2000. Special report on emissions scenarios: a special report of Working Group III of the Intergovernmental Panel on Climate Change. Cambridge University Press, Cambridge, UK.

Ostrom, E. 2009. A general framework for analyzing sustainability of social-ecological systems. Science 325 (5939):419-422. http://dx.doi.org/10.1126/science.1172133

Ostrom, E., and M. Cox. 2010. Moving beyond panaceas: a multitiered diagnostic approach for social-ecological analysis. Environmental Conservation 37(4):451-463. http://dx.doi.org/10.1017/ S0376892910000834

Pert, P. L., R. Hill, K. J. Williams, E. K. Harding, T. O’Malley, R. A. Grace, A. P. Dale, I. Bohnet, and J. R. L. A. Butler. 2010. Scenarios for community-based approaches to biodiversity conservation: a case study from the Wet Tropics, Queensland, Australia. Australian Geographer 41:285-306. http://dx.doi. org/10.1080/00049182.2010.498037

Peterson, G. D., G. S. Cumming, and S. R. Carpenter. 2003. Scenario planning: a tool for conservation in an uncertain world. Conservation Biology 17(2):358-366. http://dx.doi.org/10.1046/ j.1523-1739.2003.01491.X 
Presentan proyecto de reforma a la Ley de Pesca Artesanal que rige en Rio Negro. 2015. Lo Principal. 10 May;Sect. Río Negro. [online] URL: http://www.loprincipal.com.ar/presentan-proyectode-reforma-a-la-ley-de-pesca-artesanal-que-rige-en-rio-negro/

Reed, M. S. 2008. Stakeholder participation for environmental management: a literature review. Biological Conservation 141 (10):2417-2431. http://dx.doi.org/10.1016/j.biocon.2008.07.014

Richards, C., K. Blackstock, and C. Carter. 2007. Practical approaches to participation. SERG Policy Brief No. 1. Macaulay Institute, Aberdeen, UK. [online] URL: http://www.macaulay.ac. uk/ruralsustainability/SERG $\% 20$ PB1\%20final.pdf

Rogers, K. H., R. Luton, H. Biggs, R. Biggs, S. Blignaut, A. G. Choles, C. G. Palmer, and P. Tangwe. 2013. Fostering complexity thinking in action research for change in social-ecological systems. Ecology and Society 18(2):31. http://dx.doi.org/10.5751/ ES-05330-180231

Rojas, M., M. Zilio, S. London, M. L. Bustos, M. A. Huamantinco Cisneros, F. Scordo, F. Ferrelli, G. M. E. Perillo, M. C. Piccolo, V. Vitale, P. Bordino, L. Berninsone, and J. C. Pascale. 2014. D4.3: stakeholder visions and perspectives on the future from the Argentina case study. Deliverable 4.3 of the project COMET-LA (Community-Based Management of Environmental Challenges in Latin America), Universidad Nacional del Sur, Bahía Blanca, Argentina. [online] URL: http://www.comet-la.eu/ images/comet_la/deliverebles/Deli_4.3.pdf

Rounsevell, M. D. A., and M. J. Metzger. 2010. Developing qualitative scenario storylines for environmental change assessment. Wiley Interdisciplinary Reviews: Climate Change 1 (4):606-619. http://dx.doi.org/10.1002/wcc.63

Saunders, F. P. 2014. The promise of common pool resource theory and the reality of commons projects. International Journal of the Commons 8(2):636-656.

Scholte, P. 2003. Immigration: a potential time bomb under the integration of conservation and development. AMBIO: A Journal of the Human Environment 32(1):58-64. http://dx.doi. org/10.1579/0044-7447-32.1.58

Schreckenberg, K., I. Camargo, K. Withnall, C. Corrigan, P. Franks, D. Roe, L. Scherl, and V. Richardson. 2010. Social assessment of conservation initiatives: a review of rapid methodologies. Natural Resource Issues No. 22. International Institute for Environment and Development, London, UK. [online] URL: http://pubs.iied.org/pdfs/14589IIED.pdf

Schwerdt, J. I. 2015. La ley de Pesca Artesanal, con nuevo impulso en Diputados. La Neuva (Bahía Blanca, Argentina). 31 May;Sect. The region. [online] URL: http://www.lanueva.com/la-regionimpresa/814638/la-ley-de-pesca-artesanal--con-nuevo-impulso-endiputados.html

Shackleton, C. M., T. J. Willis, K. Brown, and N. V. C. Polunin. 2010. Reflecting on the next generation of models for communitybased natural resources management. Environmental Conservation 37(1):1-4. http://dx.doi.org/10.1017/S0376892910000366

Stem, C., R. Margoluis, N. Salafsky, and M. Brown. 2005. Monitoring and evaluation in conservation: a review of trends and approaches. Conservation Biology 19(2):295-309. http://dx. doi.org/10.1111/j.1523-1739.2005.00594.X

van Notten, P. W. F., J. Rotmans, M. B. A. van Asselt, and D. S. Rothman. 2003. An updated scenario typology. Futures 35 (5):423-443. http://dx.doi.org/10.1016/S0016-3287(02)00090-3

Waylen, K. A., A. Fischer, P. J. K. McGowan, and E. J. MilnerGulland. 2013. Deconstructing community for conservation: why simple assumptions are not sufficient. Human Ecology 41 (4):575-585. http://dx.doi.org/10.1007/s10745-013-9594-8

Waylen, K. A., J. Martin Ortega, K. L. Blackstock, and I. Brown. 2014. The COMET-LA scenario-planning methodology. The James Hutton Institute, Aberdeen, UK. [online] URL: http:// www.hutton.ac.uk/sites/default/files/files/projects/COMET-LA\% 20scenario $\% 20$ method.pdf

Western, D., S. C. Strum, and M. R. Wright, editors. 1994. Natural connections: perspectives in community-based conservation. Island, Washington, D.C., USA.

Wollenberg, E., D. Edmunds, and L. Buck. 2000. Using scenarios to make decisions about the future: anticipatory learning for the adaptive co-management of community forests. Landscape and Urban Planning 47(1-2):65-77. http://dx.doi.org/10.1016/S0169-2046 (99)00071-7

Wright, G., and P. Goodwin. 2009. Decision making and planning under low levels of predictability: enhancing the scenario method. International Journal of Forecasting 25(4):813-825. http://dx.doi. org/10.1016/j.ijforecast.2009.05.019 
Appendix 1. An extract of a portion of the matrix resulting from the process of 'morphological analysis'.

Table A1.1 The following table presents one set of row and columns from the matrix of drivers and variables used in the Mexican case, to illustrate the results of carrying out 'morphological analysis'. In this case, the complete matrix contained seven variables, each previously identified by the community as a key aspect of the local socio-ecological system. The matrix contents were used during the creation of alternative contrasting future scenarios. For more information about the drivers and all the system variables included in this matrix see Escalante Semerena et al. (2014).

\begin{tabular}{|c|c|c|c|c|c|c|c|c|c|c|}
\hline \multirow{3}{*}{$\begin{array}{l}\text { System } \\
\text { variable }\end{array}$} & \multicolumn{10}{|c|}{ Drivers of change } \\
\hline & \multicolumn{2}{|c|}{$\begin{array}{l}\text { Social driver: } \\
\text { Tightening/ loosening } \\
\text { immigration controls in US }\end{array}$} & \multicolumn{2}{|c|}{$\begin{array}{l}\text { Technological driver: } \\
\text { Change in timber harvesting } \\
\text { machinery }\end{array}$} & \multicolumn{2}{|c|}{$\begin{array}{l}\text { Environmental driver: } \\
\text { Climate change }\end{array}$} & \multicolumn{2}{|c|}{$\begin{array}{l}\text { Economic driver: } \\
\text { Changes in global } \\
\text { market prices for timber } \\
\text { products }\end{array}$} & \multicolumn{2}{|c|}{$\begin{array}{l}\text { Political driver: } \\
\text { Mexican Political } \\
\text { stability }\end{array}$} \\
\hline & $\begin{array}{l}\text { State 1: } \\
\text { US } \\
\text { immigration } \\
\text { controls } \\
\text { tighten and } \\
\text { allow fewer } \\
\text { entries per } \\
\text { year }\end{array}$ & $\begin{array}{l}\text { State 2: US } \\
\text { immigration } \\
\text { controls are } \\
\text { relaxed and } \\
\text { allow more } \\
\text { entries per } \\
\text { year }\end{array}$ & $\begin{array}{l}\text { State 1: } \\
\text { Improvement } \\
\text { reducing } \\
\text { production } \\
\text { costs }\end{array}$ & $\begin{array}{l}\text { State 2: } \\
\text { Technology } \\
\text { remains the } \\
\text { same and } \\
\text { productions } \\
\text { costs } \\
\text { increase }\end{array}$ & $\begin{array}{l}\text { State 1: } \\
\text { Temperatures } \\
\text { increase } \\
\text { slightly, } \\
\text { rainfall } \\
\text { patterns } \\
\text { remain similar } \\
\text { to today }\end{array}$ & $\begin{array}{l}\text { State 2: } \\
\text { Temperatures } \\
\text { increase 2C, } \\
\text { rainfall } \\
\text { decreases } \\
\text { significantly }\end{array}$ & $\begin{array}{l}\text { State 1: } \\
\text { Timber } \\
\text { prices go up }\end{array}$ & $\begin{array}{l}\text { State 2: } \\
\text { Timber } \\
\text { prices go } \\
\text { down }\end{array}$ & $\begin{array}{l}\text { State 1: } \\
\text { Self- } \\
\text { defence } \\
\text { forces are } \\
\text { not in the } \\
\text { territory }\end{array}$ & $\begin{array}{l}\text { State 2: } \\
\text { Self- } \\
\text { defence } \\
\text { forces } \\
\text { appear in } \\
\text { the territory }\end{array}$ \\
\hline $\begin{array}{l}\text { Extraction } \\
\text { levels and } \\
\text { exclusion } \\
\text { rights of } \\
\text { forestry }\end{array}$ & $\begin{array}{l}\text { Extraction } \\
\text { levels } \\
\text { increase to } \\
\text { satisfy } \\
\text { population's } \\
\text { needs }\end{array}$ & $\begin{array}{l}\text { Extraction } \\
\text { levels would } \\
\text { reduce as } \\
\text { demand } \\
\text { reduces }\end{array}$ & $\begin{array}{l}\text { Increased } \\
\text { extraction } \\
\text { levels, with } \\
\text { exclusion of } \\
\text { external } \\
\text { individuals }\end{array}$ & $\begin{array}{l}\text { Extraction } \\
\text { levels would } \\
\text { decrease }\end{array}$ & $\begin{array}{l}\text { Levels of } \\
\text { extraction } \\
\text { levels and } \\
\text { exclusion } \\
\text { would remain } \\
\text { constant }\end{array}$ & $\begin{array}{l}\text { Extraction } \\
\text { levels would } \\
\text { be lower as } \\
\text { forest system } \\
\text { changes }\end{array}$ & $\begin{array}{l}\text { Increased } \\
\text { extraction } \\
\text { levels and } \\
\text { increased } \\
\text { exclusion of } \\
\text { external } \\
\text { individuals }\end{array}$ & $\begin{array}{l}\text { Extraction } \\
\text { levels and } \\
\text { external } \\
\text { exclusion } \\
\text { would both } \\
\text { be lower }\end{array}$ & $\begin{array}{l}\text { Extraction } \\
\text { levels and } \\
\text { external } \\
\text { exclusion } \\
\text { would both } \\
\text { be lower }\end{array}$ & $\begin{array}{l}\text { Extraction } \\
\text { and rights } \\
\text { to access } \\
\text { would } \\
\text { controlled } \\
\text { by external } \\
\text { and violent } \\
\text { groups }\end{array}$ \\
\hline
\end{tabular}


Appendix 2. Topics used to discuss experiences of each stage of the methodology

This guide was sent to each case study team prior to each debriefing interview. It was adapted and expanded to add questions specific to the team, stage of the methodology and outputs from it. The questions also formed the basis of a topic guide used during the interview. The topic guide was not explicitly or solely framed in terms of the potential benefits in which this study is framed, so as to allow an openness to understanding any and all of the experiences of using the method, and also because some information (e.g. who participated in the workshops) was derived from reports on the outputs of activities on each stage.

Introductory and overview questions:

1. How familiar was the team with the tasks before you used them in the case study?

2. How did it go in general? Was it a positive step forward or a distraction?

3. What was the most surprising outcome or event during this task?

\section{Outcomes and experiences:}

4. What new knowledge or ideas were discovered in this stage?

- By whom? Do you think that this could this have happened without the scenario methods being used?

5. Did the task expose divergence or differences in views?

- What and why? With whom within the community and/or project team?

6. Did the task facilitate convergence or promote consensus-building?

- How/why? With whom?

7. Did these tasks help communities develop systems thinking? Adaptive management?

○ How/why?

\section{Methodological changes:}

8. Did the work change/ did you deviate from your plan? Why?

9. Was it your idea to change the plan, or were you responding to views from the community/stakeholders?

10. With the benefit of hindsight, would you do anything differently if you did this again?

O Why?

$\circ$ Would you do this task again? Was it necessary? Useful?

- If you had more time and resources, what would you do anything additional? Would you exclude something?

\section{Next steps:}


11. Are you clear about the outputs we are hoping to see from this stage and when can we expect them?

12. Has completing this stage of work influenced your plans for the next stage of work? How?

13. Are you clear on what you are doing in the next stage? When do you plan to complete the next stage?

14. Any other issues? Any other factors relevant to the case study that might have influenced how this stage went? (e.g. local elections, environmental crises, media controversies etc)? 